\title{
Procjena uspješnosti protetičke rehabilitacije osoba s amputacijom donjeg uda
}

\section{Evaluation of prosthetic rehabilitation success in patients with lower limb amputation}

\author{
Tanja Grubić Kezele ${ }^{1 *}$, Dunja Mršić ${ }^{2}$, Endi Radović ${ }^{2}$ Ariana Fužinac-Smojver ${ }^{3}$
}

${ }^{1}$ Zavod za fiziologiju i imunologiju, Medicinski fakultet Sveučilišta u Rijeci, Rijeka

${ }^{2}$ Zavod za fizikalnu i rehabilitacijsku medicinu s reumatologijom - lokalitet Sušak, Klinički bolnički centar Rijeka, Rijeka

${ }^{3}$ Katedra za temeljne medicinske znanosti, Fakultet zdravstvenih studija Sveučilišta u Rijeci, Rijeka
Sažetak. Cilj: Protetička rehabilitacija nakon amputacije donjeg uda uključuje sve kompleksne postupke i interakcije rehabilitacijskog tima i pacijenta koje su usmjerene cilju uspostavljanja sigurnog i stabilnog hoda s protezom. Nakon otpuštanja iz rehabilitacijskog centra pacijent koristi protezu, sukladno dobi, stilu života i okolini u kojoj živi. Cilj: Cilj rada je procijeniti uspješnost protetičke rehabilitacije osoba $s$ amputacijom donjeg uda koristeći indekse predviđene mobilnosti pacijenta (engl. Amputee Mobility Predictor; AMP) i brzinu hoda. Ispitanici i metode: $\mathrm{U}$ radu su korišteni podaci pacijenata iz baze podataka Zavoda za fizikalnu i rehabilitacijsku medicinu Kliničkog bolničkog centra u Rijeci, a pri tome su u skladu s Helsinškom deklaracijom ostali anonimni: dob, spol, vrsta i strana amputacije, AMP, brzina hoda i vrijeme provedeno u protezi. Od sto pacijenata s amputacijom 62 su bila transtibijalna (TT) i 38 transfemoralna (TF). U ispitivanju je sudjelovalo 27 žena i 73 muškarca. Svim pacijentima je utvrđen AMP indeks prije rehabilitacijskog postupka (AMPnoPRO) te nakon završenog rehabilitacijskog postupka (AMPPRO). Rezultati: Nakon provedene protetičke rehabilitacije utvrđena je statistički značajna razlika u konačnoj mobilnosti (AMP: $p<0,001)$ i brzini hoda $(p=0,002)$ između TT i TF grupa, odnosno bolji rezultat su postigli pacijenti s nižom razinom amputacije (TT). Također je utvrđena statistički značajna povezanost između vremena provedenog u protezi i brzini hoda te AMP indeksa $(p<0,001)$. Zaključak: Razina amputacije je važna stavka koja pridonosi konačnom ishodu rehabilitacijskog postupka, odnosno viša razina amputacije kod pacijenata (TF) predstavlja jedan oblik ograničenja za bolji uspjeh u odnosu na pacijente s nižom razinom amputacije (TT).

Ključne riječi: amputacija; Amputee Mobility Predictor; brzina hoda; protetička rehabilitacija

Abstract. Aim: Prothetic rehabilitation after lower limb amputation includes all complex procedures and interactions between the rehabilitation team and the patient aimed for establishing a safe and stable walk with the prosthesis. After being released from the rehabilitation center, the patient uses the prosthesis, according to age, lifestyle and the environment in which he lives. Aim: The aim of the paper is to evaluate the success of the prosthetic rehabilitation after lower limb amputation patients using Amputee Mobility Predictor (AMP) and walking speed measures. Patients and methods: The following patients' data ware taken from the database at the Department of Physical and Rehabilitation Medicine of the Clinical Hospital Center Rijeka, used in purpose of this work only, and stayed anonymous according to the Helsinki Declaration: age, sex, type and side of amputation, AMP, walking speed and the time spent in the prosthesis. From the 100 patients with amputation, 62 of them was transtibial (TT) and 38 transfemoral (TF). The AMP index was established for all patients prior to the rehabilitation procedure (AMPnoPRO) and after the completed rehabilitation procedure (AMPPRO). Results: After the prosthetic rehabilitation, a statistically significant difference in ultimate mobility (AMP: $p<0,001)$ and walking speed $(p=0.002)$ between the TT and the TF group was established, respectively, in a patients with a lower level of amputation (TT). A statistically significant correlation between the time spent in the prosthesis and walking speed and AMP index $(p<0.001)$ was also established. Conclusion: The level of amputation is an important factor contributing to the ultimate outcome of the rehabilitation process, and a higher level of amputation in patients (TF) is one form of limitation for better success compared to patients with lower amputation levels (TT).

Key words: amputation; Amputee Mobility Predictor; prosthetic rehabilitation; speed of walk

http://hrcak.srce.hr/medicina 


\section{UVOD}

Rehabilitacija nakon amputacije donjeg uda zahtijeva značajan rad na oporavku. Kompleksan je proces zamjene funkcije dijela tijela koji nedostaje, normalnog vanjskog izgleda, psihološke i socijalne rehabilitacije i reintegracije. U literaturi se navodi sedam ljudskih potreba osoba s amputacijom ekstremiteta: fizička funkcija s protezom, vizualno i auditivno prihvaćanje proteze, udobnost, potrošnja energije u korištenju proteze, postignuća u različitim aktivnostima s protezom, ekonomska sigurnost te status i poštovanje u društvu ${ }^{1}$.

Nakon amputacije noge većina pacijenata je spremna za umjetnu nogu (protezu). Komponente mogu uključivati stopalnu, koljenu jedinicu, skeletnu cijev i razne adaptere ovisno o razini amputacije (Slika 1). Novije proteze omogućuju ljudima da preciznije upravljaju kretnjama.

Rehabilitacija uključuje vježbe za opće kondicioniranje i vježbe za jačanje mišića. Osoba se potiče da započne vježbe što je prije moguće. Kod nekih su pacijenata potrebne i vježbe izdržljivosti. Specifičan propisani program ovisi o tome je li jedna ili su obje noge amputirane i koliko je noge amputirano ${ }^{2}$.

Treba naglasiti da je rehabilitacija pacijenata kojima su amputirani udovi iznimno složen i zahtjevan proces. Preduvjet uspješne rehabilitacije je timski, interdisciplinarni, koordinirani rad različitih zdravstvenih djelatnika: liječnika fizijatra, ortopeda, kirurga, fizioterapeuta, radnih terapeuta i medicinskih sestara te psihologa, psihijatra i socijalnih radnika. Ako je potrebno, treba uključiti i

Preduvjet uspješne rehabilitacije je timski, interdisciplinarni, koordinirani rad različitih zdravstvenih djelatnika: liječnika fizijatra, ortopeda, kirurga, fizioterapeuta, radnih terapeuta i medicinskih sestara te psihologa, psihijatra i socijalnih radnika.

specijaliste $s$ drugih područja. Osoba s amputiranim udom treba biti u centru interesa te također aktivan član tima.

Nadalje, bitnu ulogu u rehabilitaciji osoba s amputacijom udova imaju i inženjeri ortopedske tehnike i tehničari. Specifičnosti rehabilitacije osoba $s$
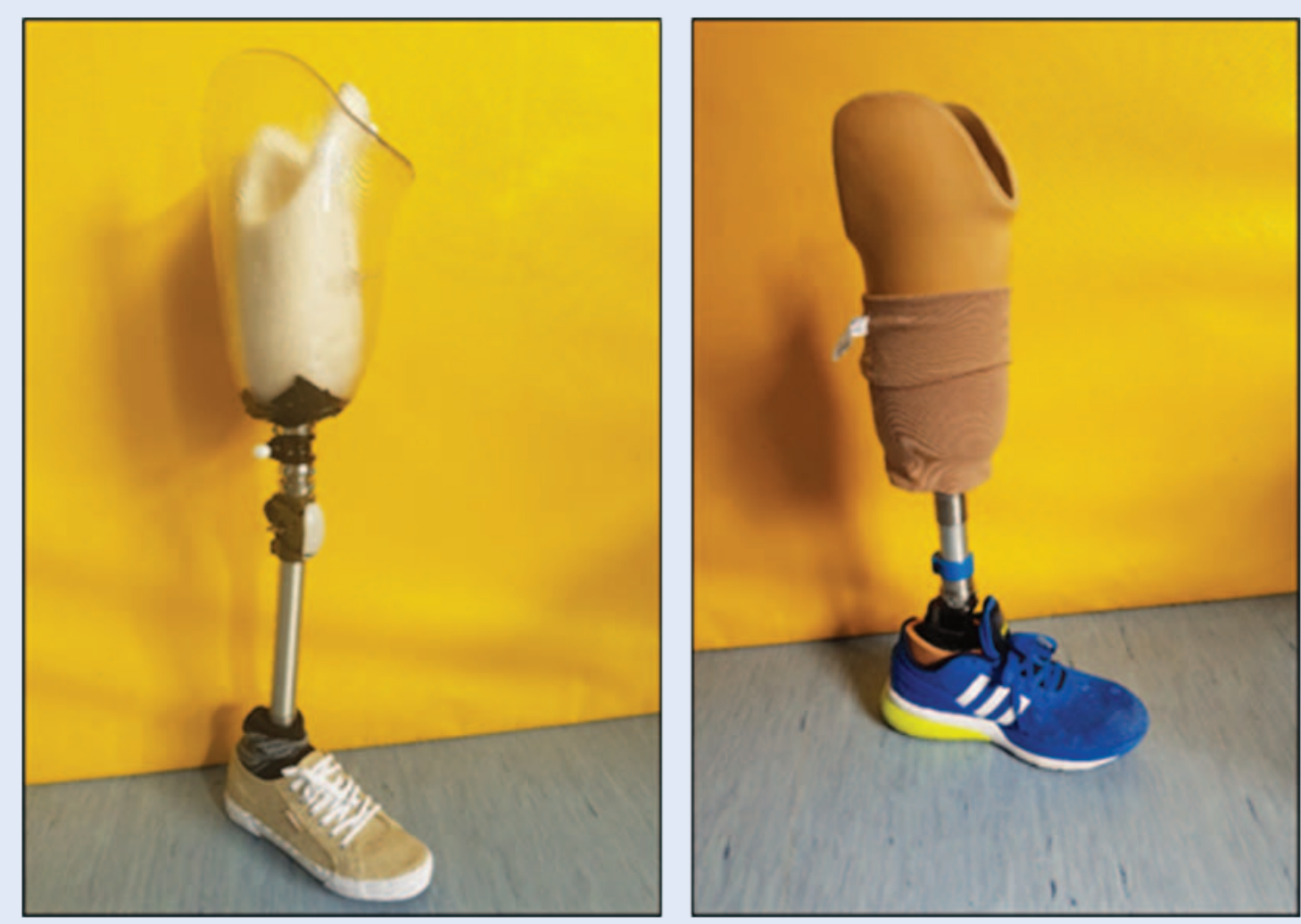

Slika 1. Natkoljene (lijevo) i potkoljene (desno) proteze. Slikano: Zavod za fizikalnu i rehabilitacijsku medicinu, KBC Rijeka. 
amputacijama predstavljaju učinkovita i koordinirana suradnja s ortopedskom tehnikom te svladavanje specifičnih znanja i usvajanje novih spoznaja vezanih uz protetičku tehnologiju od strane zdravstvenih djelatnika. Nadalje, amputacija ekstremiteta uvijek je ireverzibilan fizički fenomen koji kod osobe koja je doživjela amputaciju izaziva niz psiholoških i psihosocijalnih posljedica. Najveći izazov za pacijenta je prihvaćanje proteze kao umjetne zamjene za izgubljeni dio ekstremiteta ${ }^{2}$.

Rehabilitacija uključuje sve kompleksne postupke i interakcije rehabilitacijskog tima i pacijenta $s$ amputacijom noge koje su usmjerene cilju uspostavljanja sigurnog i stabilnog hoda s protezom. Kada se radi o vremenskom slijedu, razlikuje se nekoliko faza rehabilitacije: predoperacijska faza, postoperacijska faza, predprotetička faza, protetička faza i faza dugotrajnog kliničkog praćenja. Nakon što se obavi primarna protetička rehabilitacija pacijentu se mora omogućiti dugotrajno praćenje s intermitentnim kontrolama liječenja. Cilj je bio procijeniti uspješnost protetičke rehabilitacije osoba s amputacijom donjeg uda koristeći test provjere predviđene mobilnosti pacijenta nakon amputacije (engl. Amputee Mobility Predictor; AMP) i brzinu hoda na 10 metara.

\section{ISPITANICI I METODE}

\section{Ispitanici}

Istraživanje je provedeno na ukupno 100 bolničkih pacijenata, prosječne dobi $67,72 \pm 9,5$ godina, 62 su transtibijalna, a 38 transfemoralnih. Većinom su bili zastupljeni muškarci ( $\mathrm{N}=73$ ) (Tablica 1 ).

Podaci (mjerenja testovima AMP, brzina hoda, vrijeme provedeno u protezi, razina i strana amputacije, kao i dob i spol) su uzeti iz baze podataka Zavoda za fizikalnu i rehabilitacijsku medicinu, što

Tablica 1. Karakteristike ispitanika

\begin{tabular}{|l|c|}
\hline \multicolumn{1}{|c|}{ Karakteristike } & Vrijednost \\
\hline $\mathrm{N}$ & 100 \\
\hline Starost $(\mathrm{g})$, srednja vrijednost $\pm \mathrm{SD}^{\mathrm{a}}$ & $67,7 \pm 9,5$ \\
\hline Spol $(\mathrm{N}), \mathrm{Z̆}^{\mathrm{b}} / \mathrm{M}^{\mathrm{c}}$ & $27 / 73$ \\
\hline Razina amputacije $(\mathrm{N}), \mathrm{TT}^{\mathrm{d}} / \mathrm{TF}^{\mathrm{e}}$ & $62 / 38$ \\
\hline Strana $(\mathrm{N}), \mathrm{D}^{\mathrm{f}} / \mathrm{L}^{\mathrm{g}}$ & $54 / 46$ \\
\hline
\end{tabular}

Tumačenje kratica: ${ }^{a} \mathrm{SD} ;{ }^{b}$ žena; ${ }^{c}$ muškarac; ${ }^{\mathrm{d}}$ transtibijalno; ${ }^{\mathrm{e}}$ transfemoralno; ${ }^{f}$ desno; ${ }^{g}$ lijevo je odobrilo Etičko povjerenstvo Kliničkog bolničkog centra u Rijeci. Kod svih se pacijenata radilo o unilateralnoj amputaciji i prilikom opskrbe korištena je stopalna jedinica $\mathrm{SACH}+\mathrm{i}$ jednoosovinsko koljeno s kočnicom. Pacijenti su bili podvrgnuti procjeni mobilnosti i funkcionalnoj neovisnosti kod prijema na odjel i pri otpustu nakon provedene rehabilitacije u trajanju od 3 do 4 tjedna.

Podaci su ostali isključivo anonimni te se svakom pacijentu dodijelio broj umjesto osobnih podataka. Uključujući faktori su bili amputacija donjeg uda unutar godine dana, očuvana i intaktna koža bataljka, dobivena potvrda specijalista kardiologa za protetičku opskrbu - EF (ejekcijska frakcija) veća od $40 \%$, a isključujući faktori EF srca manja od $40 \%$, prominentnost tibije ili fibule, defekti kože, nemogućnost održavanja uspravnog stava uz pomagalo duže od 3 min, MMT (manualni mišićni test) ispod ocjene tri.

\section{Metode}

\section{Bandaža i protetička opskrba}

Ciljevi rehabilitacije usmjereni su prema pripremi bataljka za primjenu proteze, podizanju konicije pacijenta i pripremi za napore protetičke rehabilitacije, postizanju samostalne pokretljivosti s pomagalom za kretanje i ostvarivanje što veće neovisnosti pacijenta u aktivnostima svakodnevnog života (2). Vrlo važnu ulogu u smanjenju edema i bola, formiranju bataljka (koničan, cilindričan), privikavanju bataljka na pritisak i tonizaciji muskulature ima pravilna bandaža (Slika 2).

Protetička faza rehabilitacije je razdoblje rehabilitacije u kojem se planira i provodi protetička opskrba, a ona obuhvaća odabir vrste proteze i njezinih pojedinih dijelova, izradu i primjenu proteze na kojoj se provode statičke korekcije radi optimalne biomehaničke prilagodbe s pratećom rehabilitacijom i svladavanjem hoda te ostalih fizičkih aktivnosti s protezom u trajanju od $3-4$ tjedna, 6 dana u tjednu, 4 h na dan (2) (Slika 3). Nakon otpuštanja iz rehabilitacijskog centra pacijent koristi protezu, sukladno dobi, stilu života i okolini u kojoj živi. U načelu, za aktivne osobe je cilj cjelodnevna upotreba proteze u svim aktivnostima svakodnevnog života (radnim i rekreacijskim), a za starije osobe je dobar rezultat vremenski i prostorno ograničeno korištenje proteze ${ }^{2}$. Vrlo važna či- 

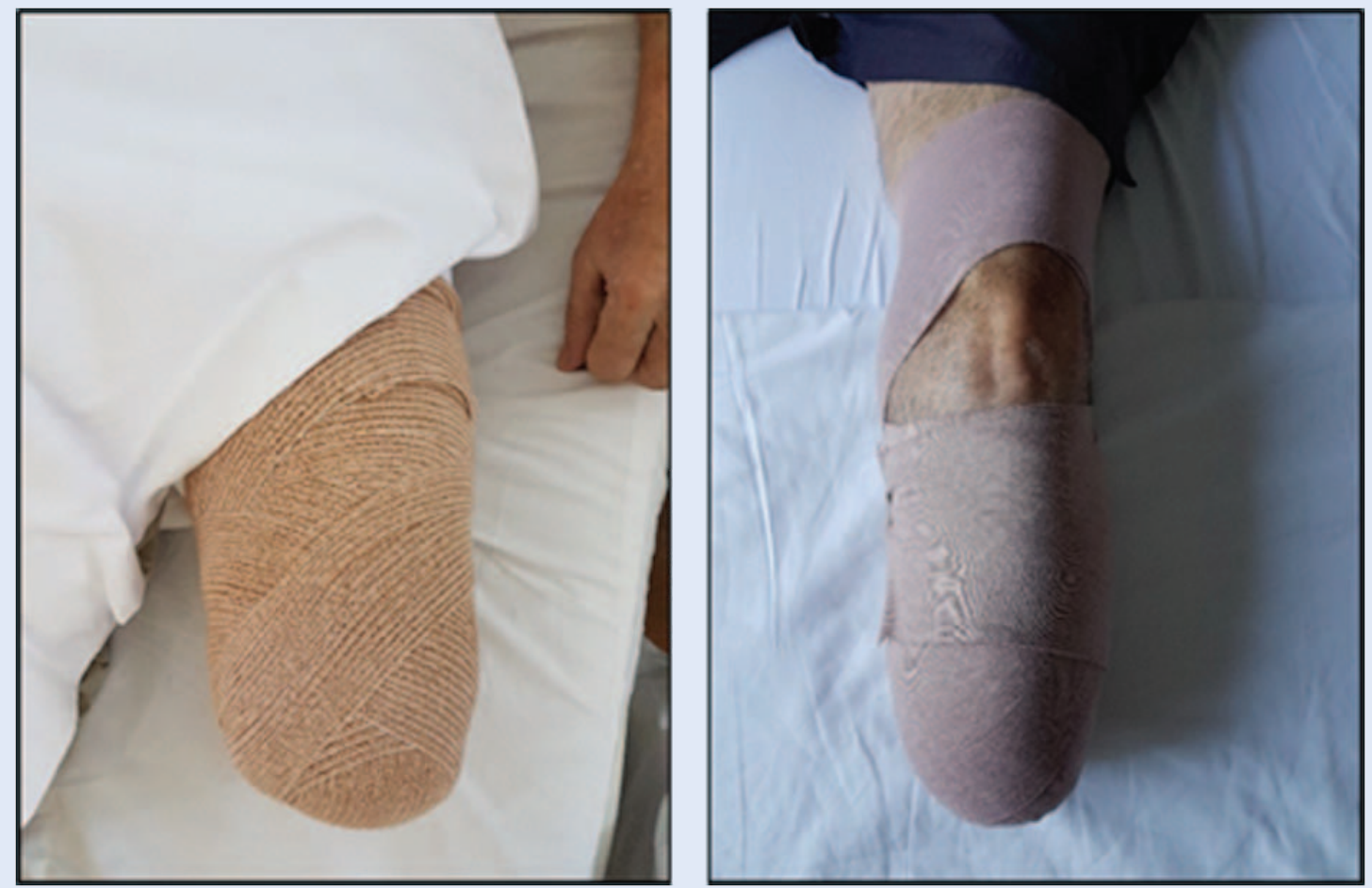

Slika 2. Bandaže natkoljenog (lijevo) i potkoljenog (desno) bataljka. Slikano: Zavod za fizikalnu i rehabilitacijsku medicinu, KBC Rijeka.
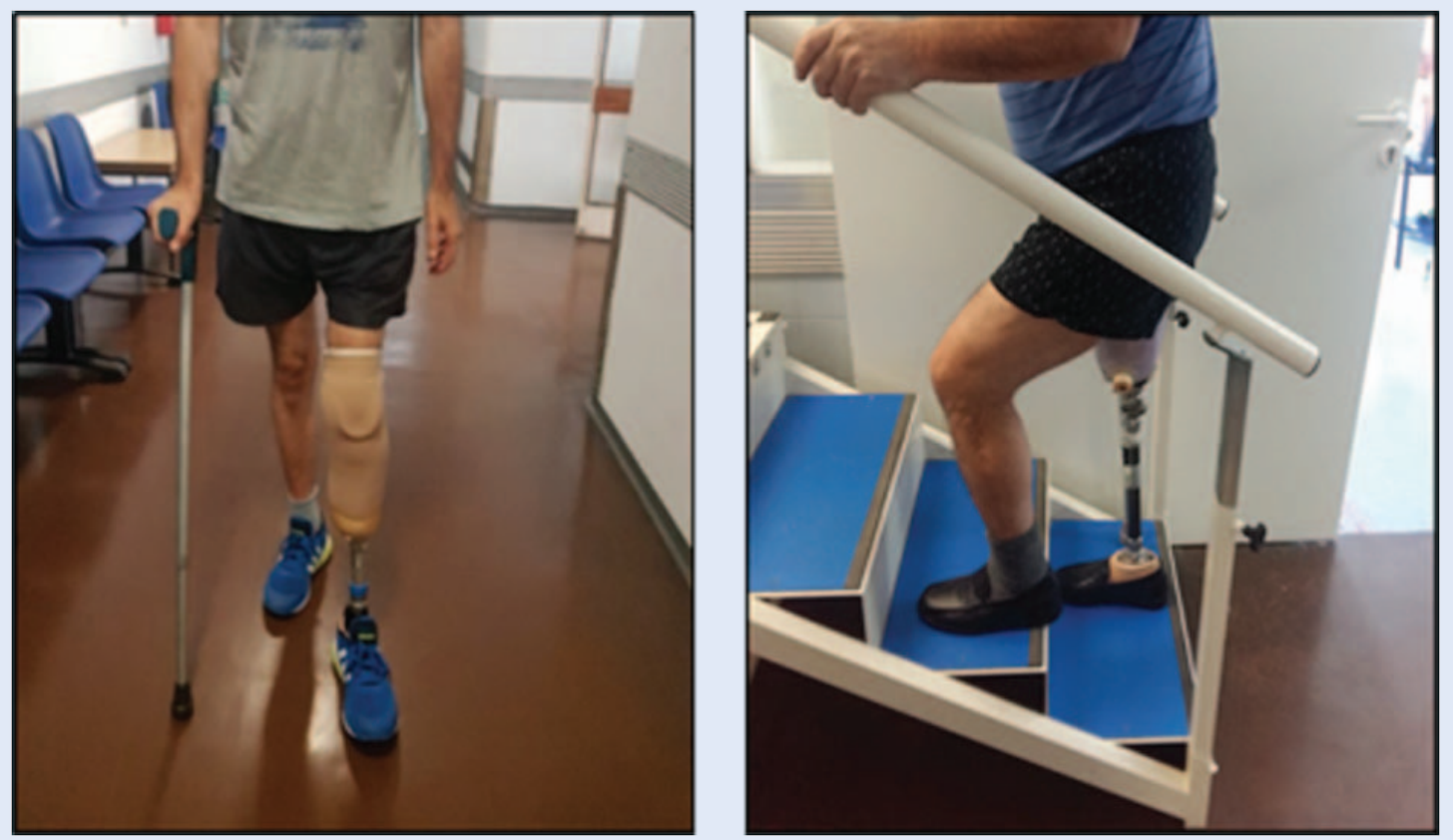

Slika 3. Hod s potkoljenom (lijevo) i natkoljenom (desno) protezom u prirodnom prostoru. Slikano: Zavod za fizikalnu i rehabilitacijsku medicinu, KBC Rijeka.

njenica prilikom završetka rehabilitacije je vizualno prihvaćanje sebe nakon opskrbe, stoga je bitno protezu adaptirati najbolje moguće za pojedinca te osigurati kozmetički dio proteze, čime se približavamo vizualno zdravoj strani tijela.

\section{Amputee mobility predictor}

AMP je pouzdan i valjan ${ }^{3}$, a ujedno brz i jednostavan alat za procjenu odnosno mjerenje funkcionalnog statusa amputacija donjih udova sa i bez upotrebe proteze $\mathrm{e}^{2,3}$. 
Test je osmišljen da bude klinički izvediv, traje manje od 10 do 15 minuta te zahtijeva vrlo malo opreme. Engleska inačica je preuzeta $s$ internetske baze kliničkih upitnika (4), a prevela su je dva nezavisna prevoditelja (autora), te je usporedbom dvaju prijevoda konstruirana konačna verzija upitnika (Prilog).

AMP indeksom procjenjuje se pokretljivost osoba nakon amputacije donjeg uda te postojeće ili potencijalne funkcionalne mogućnosti. Svaka stavka uključena u AMP odabrana je za njegov doprinos cjelokupnoj procjeni funkcije osoba nakon amputacije.

Rehabilitacija uključuje sve kompleksne postupke i interakcije rehabilitacijskog tima i pacijenta s amputacijom noge koje su usmjerene cilju uspostavljanja sigurnog i stabilnog hoda s protezom.

Upitnik AMP temelji se na objektivnim mjerenjima $\mathrm{i}$ ispituje šest različitih domena pokretljivosti: sjedeći balans, transfer, stojeći balans, hod, hod po stubama i korištenje pomagala kroz ukupno 21 stavku. Upitnik predviđa i registrira potencijal pacijenta za prihvaćanje i korištenje proteze.

Ukupni raspon rezultata za AMP indeks je 0 do 42 boda. Više vrijednosti AMP indeksa upućuju na bolji rezultat ispitivane osobe. Bodovanje stavki pod brojem 1, 11, 14, 15 i 16 vrši se kroz dva odabira (0 i 1), dok se bodovanje stavki 2, 3, 4, 5, 6, 7, $8,9,10,12,13,17,18,19$ i 20 boduje kroz tri odabira (0, 1 ili 2): 0 označava nemogućnost izvršavanja zadataka, 1 znači minimalnu razinu postignuća ili da je neka pomoć bila potrebna u izvršenju zadatka i 2 označava potpunu neovisnost ili ovladavanje zadatkom. U testu AMPnoPRO (bez proteze) najveći mogući rezultat je 38 bodova jer se eliminira stavka 8 (stajanje na jednoj nozi što nije moguće jer pacijent nije protetički opskrbljen) te ukupni broj stavki iznosi 20.

Kroz posljednju 21. stavku povećavaju se mogućnosti potencijalnih ukupnih bodova subjekata za 5 bodova (na 43 i 47 boda za AMPnoPRO i AMPRO), ovisno o vrsti pomagala koje se koristi tijekom testiranja ${ }^{3}$.

Brzina hoda je test koji se testira na kraju provedene rehabilitacije i škole hoda. Prilikom testiranja koristi se štoperica, hoda se ravnom površinom duljine 10 metara. Svaki pacijent prolazi zadanu dužinu po 4 puta nakon čega se uzima srednja vrijednost izražena u m/s (metar u sekundi) i upisuje se u fizioterapeutski karton.

\section{Statistička obrada podataka}

Rezultati dobiveni istraživanjima statistički su obrađeni pomoću računalnog programa Statistica verzije 13 (Sigma Plot Scientific Graphing System, v13.0.).

Prije testiranja značajnosti razlika između varijabli koje su predmet ovog istraživanja (AMP i brzina hoda), izabran je najprimjereniji statistički test s obzirom na normalnost raspodjele podataka. Normalna raspodjela podataka za AMP i brzinu hoda $(p>0,05)$ je potvrđena Kolmogorov-Smirnovljevim testom.

Za ispitivanje razlika u učinku djelovanja terapije između pojedinih grupa (TT i TF) AMPnoPRO i AMPRO) korištena je analiza varijance za ponavljana mjerenja - miješani model (engl. 2-way mixed-model, repeated-measures analyses of variance - ANOVA), odnosno ANOVA s uključenim vremenom (prije i poslije) kao unutargrupnim čimbenikom te grupama (AMPnoPRO i AMPRO) kao međugrupnim čimbenikom ${ }^{5,6}$. Za usporedbu podataka unutar i među grupama korištena je jednosmjerna ANOVA i post hoc Tukey-Kramerov test za nejednaki broj uzoraka.

Rezultati su izraženi kao srednja vrijednost (SV) sa standardnom pogreškom (SP) ili devijacijom (SD). Za korelaciju numeričkih podataka je korišten Pearsonov test, a za kategoričke podatke Spearmanov test. Statistički značajne promjene su smatrane uz $p<0,05$.

\section{REZULTATI}

\section{Razlika u AMP indeksu kod prijema i otpusta između grupa}

Uspoređujući AMP vrijednosti kod prijema između TT i TF grupa, možemo zaključiti da kod prijema, odnosno prije započinjanja rehabilitacijskog postupka nema statistički značajne razlike ( $p=$ $0,973)$, te da su pacijenti s transtibijalnom i transfemoralnom amputacijom jednako teško pokretni (Slika 4). Usporedbom podataka između TT i TF grupa nakon rehabilitacije pri otpustu, utvrđena je statistički značajna razlika $(p=0,035)$, odnosno 
da pacijenti s nižom razinom amputacije (TT) imaju nešto bolji ishod (Slika 4).

\section{Razlika u AMP indeksu između prijema i otpusta unutar grupa}

Utvrđena je statistički značajna razlika unutar TT grupe $(p<0,001)$, kao i unutar TF grupe $(p<0,001)$ (Slika 4), odnosno pacijenti su nakon rehabilitacije postizali više prosječne vrijednosti AMP indeksa u usporedbi s rezultatima prije rehabilitacije.

\section{Ishod protetičke rehabilitacije prema AMP indeksu}

Uspoređujući konačne ishode vezane za AMP vrijednosti između dvije grupe pacijenata (TT i TF) utvrđeno je da postoji statistički značajna razlika, odnosno da je TT grupa postigla bolji uspjeh nakon provedene rehabilitacije (ANOVA za ponavljana mjerenja: $p<0,001$ ) (Slika 5).

\section{Brzina hoda i razina amputacije}

Spearmanovim korelacijskim testom utvrđeno je statistički značajno postojanje veze $(r=-0,38$; $p<0,001$ ), odnosno da nižu razinu amputacije prati veća brzina hoda. Drugim riječima, pacijenti s opsežnijom amputacijom (TF) su sporiji od onih s manje opsežnom amputacijom (TT).

\section{Usporedba brzine hoda između grupa}

Usporedbom brzine hoda između dvije grupe pacijenata (TT i TF) utvrđena je statistički značajna razlika ( $p=0,002)$, odnosno grupa s nižom razinom amputacije (TT) postiže veću brzinu hoda nakon rehabilitacijskog postupka (Slika 6.).

\section{Povezanost vremena provedenog u protezi, brzine hoda i AMP indeksa}

Ispitivanjem povezanosti između AMP indeksa i brzine hoda korelacijskim Pearsonovim testom utvrđeno je statistički značajno srednje jako postojanje veze $(r=0,60 ; p<0,001)$, odnosno da osobe $s$ bržim hodom imaju više vrijednosti AMP indeksa. Nadalje, između vremena provedenog $u$ protezi i između AMP indeksa utvrđeno je također statistički značajno postojanje veze $(r=0,47$; $p<0,001)$, kao i između vremena provedenog $\mathrm{u}$ protezi kao i brzine hoda $(r=0,37 ; p<0,001)$. To govori da osobe koje su više vremena koristile protezu imaju u konačnici brži hod i više vrijednosti AMP indeksa.
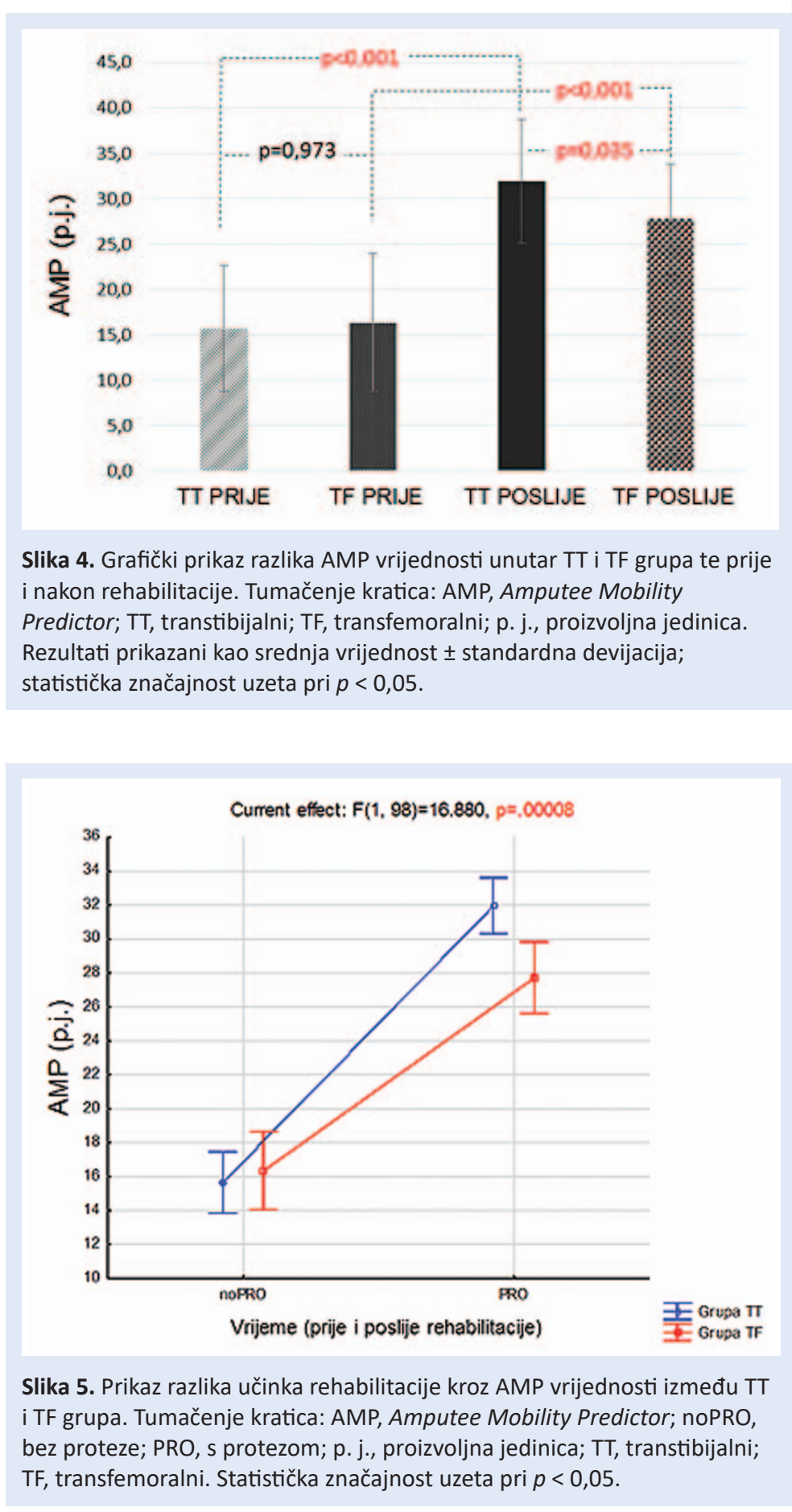

Tablica 2. Korelacija između brzine hoda, vremena provedenog u protezi i AMPPRO

\begin{tabular}{|l|l|l|}
\hline Koeficijent korelacije $r$ & AMPRO $^{c}(\mathbf{p} . \mathbf{j} .)^{\text {d }}$ & Brzina hoda $(\mathrm{m} / \mathrm{s})$ \\
\hline Brzina hoda $\left(\mathrm{m} / \mathrm{s}^{\mathrm{a}}\right)$ & $0,60(p<0,001)$ & \\
\hline Vrijeme u protezi $\left(\mathrm{h} / \mathrm{d}^{\mathrm{b}}\right)$ & $0,47(p<0,001)$ & $0,37(p<0,001)$ \\
\hline
\end{tabular}

Tumačenje kratica: ${ }^{a}$ metar u sekundi; ${ }^{b}$ sati na dan; 'Amputee Mobility Predictor bodovi poslije rehabilitacije; ${ }^{d}$ proizvoljna jedinica. Statistička obrada: Pearsonova korelacija. Statistička značajnost uzeta pri $p<0,05$. 


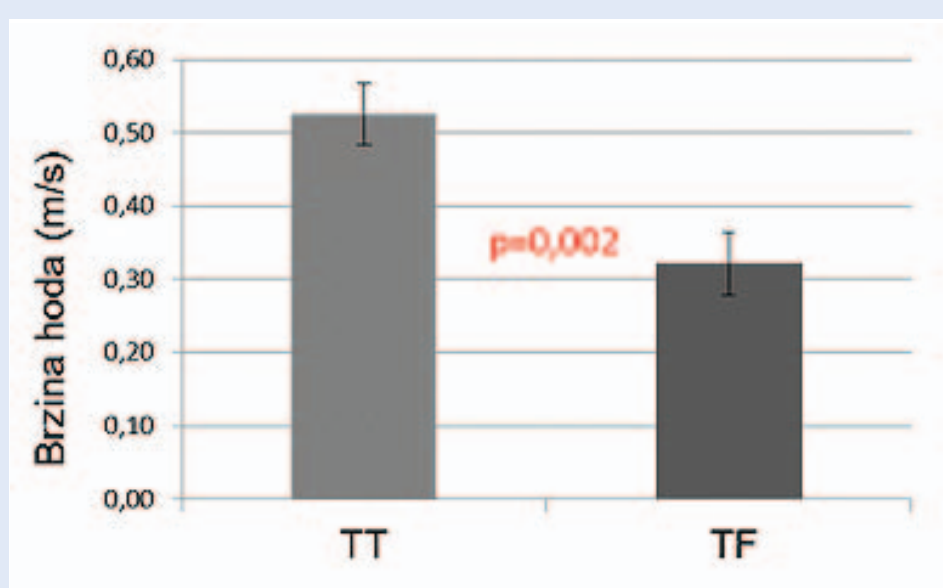

Slika 6. Grafički prikaz razlika u brzini hoda između grupa. Tumačenje kratica: TT, transtibijalni; TF, transfemoralni; m/s, minuta u sekundi. Rezultati prikazani kao srednja vrijednost \pm standardna pogreška; statistička značajnost uzeta pri $p<0,05$.

\section{RASPRAVA}

Medicinska rehabilitacija svakako mora biti popraćena odgovarajućom psihološkom i socijalnom rehabilitacijom u skladu s biopsihosocijalnim modelom. Tako se postiže krajnji cilj svake rehabilitacije, tj. uspješna reintegracija osoba s amputacijom u svakodnevni život koji sliči, što je više moguće, stilu i kvaliteti svakodnevnog života prije amputacije?.

Dobro odrađen medicinski zahvat i kvalitetno odrađena amputacija preduvjeti su za kvalitetnu protetičku rehabilitaciju i kasnije kvalitetan život pacijenta. Psiholozi navode izraz »body image«, a odnosi se na percepciju o vlastitom izgledu, misli, osjećaje i reakcije vezane uz izgled ${ }^{8}$, gdje svaka osoba ima idealiziranu sliku tijela koju koristi kao mjerilo o svom tijelu ${ }^{9}$. Promjena individualne slike tijela predstavlja niz emocionalnih, perceptivnih i psiholoških reakcija. Naime, amputacija može dovesti do dugoročnog poremećaja u doživljaju tijela pojedinca ${ }^{10}$. Većina psihosocijalnih istraživanja vezanih uz amputaciju donjih udova govore o negativnim učincima amputacije na život osobe koju je amputacija zadesila u smislu depresije, anksioznosti, tuge i žalovanja, poremećaja slike tijela te psihosocijalnih poremećaja ${ }^{11}$. Novija istraživanja pokazuju, međutim, i pozitivna optimistična razmišljanja osoba koja umanjuju simptomatologiju depresije, stoga se naglašava potreba individualne procjene rehabilitacijskog potencijala svake osobe s amputacijom ${ }^{11}$.
Mogućnost opskrbe protezom nakon amputacije ovisna je o nekoliko čimbenika: o etiologiji amputacije, razini amputacije i o dobi osobe s amputacijom. MacKenzie navodi da se kod pacijenata $s$ traumatskom amputacijom protetička opskrba i rehabilitacija uspješno ostvarila kod $97 \%$ pacijenata i to unutar 3 mjeseca nakon amputacije ${ }^{12}$. Amputacija donjih udova predstavlja jedan od klasičnih rehabilitacijskih problema intervencije fizioterapeuta. Zbog starenja stanovništva i povećanja incidencije dijabetesa očekuje se da će se broj amputacija povećati u budućnosti ${ }^{13}$. Bolju kvalitetu hoda imaju osobe koje imaju samo amputaciju jedne noge, kao i osobe kod kojih je amputacija učinjena distalnije ${ }^{14}$, dok je rizik pada veći kod transfemoralne amputacije ${ }^{15}$. Općenito se može reći da je hod osoba s amputacijom usporen i asimetričan u usporedbi sa zdravima, a sukladan njihovom poremećaju ravnoteže ${ }^{16}$.

Prema Burgeru 2011. u rehabilitaciji osoba s amputacijom udova nema puno dokaza o njenoj učinkovitosti. Naime, njegove spoznaje upućuju na to da amputacija smanjuje mišićnu snagu i ravnotežu, te da ljudi s amputacijom hodaju sporije i manje simetrično. Također navodi da bolje hodaju oni koji su fizički bolje pripremljeni, imaju amputiranu samo jednu nogu te su proveli ranu protetičku opskrbu i rehabilitaciju ${ }^{17,18}$.

Precizno praćenje pokretljivosti protetičnog ekstremiteta podrazumijeva upotrebu adekvatnih, ali i što jednostavnijih testova ${ }^{19,20}$. Uspješnost protetičke opskrbe te provedene rehabilitacije nakon amputacije donjeg uda u našem radu provodi se evaluacijskim indeksima mobilnosti pacijenata (AMP) i brzinom hoda na deset metara.

Utvrđeno je da pacijenti s TT amputacijom postižu bolji uspjeh po završetku rehabilitacije od pacijenata s TF amputacijom. Uspoređujući AMP vrijednosti kod prijema (prije početka rehabilitacijskog postupka) između TT i TF grupe utvrđuje se da nema statistički značajne razlike $(p=0,973)$, no nakon provedene rehabilitacije (prilikom otpusta nakon $3-4$ tjedna) vidljiva je statistički značajna razlika između TT i TF grupa $(p=0,035)$. To ukazuje da pacijenti s nižom razinom amputacije (TT) imaju nešto bolji ishod. Također je utvrđena statistički značajna razlika $(p=0,002)$ u brzini hoda između dviju grupa pacijenata (TT: SV $=0,52 \pm 0,04$; TF: SV =0,32 $\pm 0,04)$, iz čega zaklju- 
čujemo da grupa s nižom razinom amputacije (TT) postiže veću brzinu hoda na deset metara nakon rehabilitacijskog postupka u odnosu na pacijente s višom razinom amputacije (TF).

Rezultati studije provedene u Miamiju upućuju na to da je test 6 minutnog hoda pokazao umjereno do visok pozitivan odnos $s$ AMPnoPRO i AMPPRO indeksom. S obzirom na dob pacijenata i komorbiditete u našem istraživanju proveli smo usporedbu brzine hoda na 10 metara, AMPPRO indeksa i vremena provedenog u protezi te utvrdili da također postoji statistički značajna umjereno do srednje visoka povezanost između brzine hoda i AMP indeksa $(r=0,60 ; p<0,001)$, između vremena provedenog u protezi i AMP indeksa ( $r=$ $0,47 ; p<0,001)$ te između vremena provedenog u protezi i brzine hoda $(r=0,37 ; p<0,001)$.

Time smo dokazali da pacijenti koji su više vremena proveli u protezi imaju brži hod i bolji AMP indeks. Iz navedenog se vidi da je AMP indeks praktičan i siguran način mjerenja funkcionalnih sposobnosti kod osoba s amputacijom donjeg uda. Važno je također napomenuti da pacijenti tijekom perioda rehabilitacije, osim rehabilitacijskih vježbi s fizioterapeutom, sami počnu raditi na prihvaćanju proteze, odnosno da stvaraju i potiču pozitivnu samopercepciju, prihvaćanje proteze i interakciju s okolinom.

Naime, visoka razina socijalnog prihvaćanja i potpore povezana je $s$ boljim prihvaćanjem proteze. Nadalje, razina zadovoljstva boljitkom (u smislu kirurške obrade, postojanja fantomskih bolova i ostalih senzacija) isto je bitan aspekt u procjeni. Glavni razlozi niže razine zadovoljstva estetikom proteze kod primarne opskrbe navode se: voluminozan bataljak, loše saniran bataljak, prisutnost kontrakture i posturalnih promjena uslijed inaktiviteta te kratko iskustvo u privikavanju, svladavanju i integriranju u aktivnosti dnevnog života ${ }^{21,22}$.

Na kraju, također smatramo da je potrebno upotrijebiti i druge funkcionalne indekse osposobljenosti prilikom testiranja učinkovitosti rehabilitacijskog programa, kako bi se mogle napraviti relevantnije usporedbe s drugim istraživanjima.

\section{ZAKLJUČAK}

Rehabilitacija pacijenata $s$ amputacijom donjeg uda iznimno je složen i zahtjevan proces koji zahtijeva multidisciplinaran pristup s ciljem posti- zanja što većeg stupnja osamostaljenja u aktivnostima dnevnog života. Razina amputacije je važna stavka koja pridonosi konačnom ishodu rehabilitacijskog postupka, odnosno viša razina amputacije kod pacijenata (TF) predstavlja jedan oblik ograničenja za bolji uspjeh u odnosu na pacijente s nižom razinom amputacije (TT).

U literaturi se navodi sedam ljudskih potreba osoba $\mathrm{s}$ amputacijom ekstremiteta: fizička funkcija s protezom, vizualno i auditivno prihvaćanje proteze, udobnost, potrošnja energije u korištenju proteze, postignuća u različitim aktivnostima s protezom, ekonomska sigurnost te status i poštovanje u društvu.

Važan faktor protetičke rehabilitacije je čim ranije uključiti pacijenta u proces škole hoda te ga opskrbiti za njega najboljim protetičkim pomagalom. Naravno veoma važan dio je i primjena odgovarajućih vježbi tijekom rehabilitacije.

Svaki pacijent zahtijeva individualan pristup $u$ procijeni funkcionalnog statusa i prezentacije njihovog uspjeha.

Primjenom adekvatnih evaluacijskih upitnika dobivamo uvid u pozitivne učinke protetičke rehabilitacije i škole hoda unutar kojih zamjećujemo da, bez obzira na razinu amputacije, imamo statistički značajne promjene u mobilnosti i aktivnostima dnevnog života kod pacijenata s amputacijom donjeg uda.

Ovim istraživanjem možemo utvrditi da postoji povezanost, između vremena provedenog u protezi i brzine hoda te AMP indeksa, odnosno pacijenti koji su više vremena proveli u protezi i imaju nižu razinu amputacije (TT) u konačnici imaju brži hod i bolji AMP, a zatim najvjerojatnije i veće zadovoljstvo konačnim postignutim rezultatima rehabilitacije.

Izjava o sukobu interesa: Autori izjavljuju da ne postoji sukob interesa.

\section{LITERATURA}

1. Fishman S. Amputee needs, frustrations and behavior. Rehab Lit 1959;20:322-9.

2. Kovači I, Mužić $V$, Abramović $M$, Vuletić $Z$, Vukić $T$, Ištvanović $\mathrm{N}$ et al. Rehabilitacija osoba s amputacijom donjih udova - smjernice za klinički rad. Fiz rehabil med 2015; 27:183-211. 
3. Gailey RS, Roach KE, Applegate EB, Cho B, Cunniffe B, Licht $S$ et al. The amputee mobility predictor: an instrument to assess determinants of the lower-limb amputee's ability to ambulate. Arch Phys Med Rehabil 2002;83:613-27.

4. Sralab.org [Internet]. Chicago: Shirley Ryan Abilitylab, Inc. 2017-04 [cited 2018 Sept 9]. Available from: https:// www.sralab.org/rehabilitation-measures/.

5. Ray AD, Udhoji S, Mashtare TL, Fisher NM. A combined inspiratory and expiratory muscle training program improves respiratory muscle strength and fatigue in multiple sclerosis. Arch Phys Med Rehabil 2013;94:1964-70.

6. Grubić Kezele T, Babić M, Štimac D. Exploring the feasibility of a mild and short 4-week combined upper limb and breathing exercise program as a possible home base program to decrease fatigue and improve quality of life in ambulatory and non-ambulatory multiple sclerosis individuals. Neurol Sci 2019; Forthcoming.

7. Kuiken TA, Miller L, Lipshutz R, Huang ME. Rehabilitation of People with Lower Limb Amputation. In: Braddom R (ed). Physical Medicine and Rehabilitation. $3^{\text {rd }}$ Edition. Saunders: Elselvier, 2007;283-323.

8. Dilinghan TR, Pezzin LE, MacKenzie EJ. Limb amputation and limb deficiency, epidemiology and recent trends in United States. South Med J 2002;95:875-83.

9. Cash TF. Body-image therapy: a program for self-directed change. New York: Guilford, 1991.

10. Kolb LC. Disturbances in body image. In: Arieti S, Reiser MF (eds). American Handbook of Psychiatry. New York: Basic Books, 1959;749-69.

11. Kolb LC. Disturbances in body image. In: Arieti S, Reiser MF (eds). American Handbook of Psychiatry. New York: Basic Books, 1975;810-37.

12. MacKenzie EJ, Bosse MJ, Castillo RC, Smith DG, Webb LX, Kellam JF et al. Functional outcomes following trauma- related lower-limb amputation. J Bone Joint Surg Am 2004;86-A:1636-45.

13. Losina E, Walensky RP, Reichmann WM, Holt HL, Gerlovin $\mathrm{H}$, Solomon $\mathrm{DH}$ et al. Impact of obesity and knee osteoarthritis on morbidity and mortality in older Americans. Ann Intern Med 2011;154:217-26.

14. Huang ME, Laura AM, Lipschutz R, Kuiken TA. Rehabilitation and prosthetic restoration in lower limb amputation. In: Braddom RL (ed). Physical Medicine and Rehabilitation. Philadelphia: Saunders, 2011;277-316.

15. Sansam K, Neumann V, O'Connor R, Bhakta B. Predicting walking ability following lower limb amputation: a systematic review of the literature. J Rehabil Med 2009;41:593-603.

16. Van Velzen JM, van Bennekom CAM, Polomski W, Slootman JR, van derWoude LHV, Houdijk H. Physical capacity and walking ability after lower limb amputation: a systematic review. Clin Rehabil 2006;20:999-1016.

17. Burger H. Can the international classification off unctioning, disability and health (ICF) beusedin a prosthetics and orthotics out patient clinic? Prosthet Orthot Int 2011;35:302-9.

18. Burger H. Rehabilitacija ljudi po amputaciji. Rehab 2010; 114-20.

19. Szabad g. Diabetic foot syndrome. Orv Hetil 2011;152: 1171-7.

20. Pernot HF, de Wittel P, Lindeman E, Cluitmans J. Daily functioning of the lower extremity amputee: an overview of the literature. Clinrehabil 1997;11:93-106.

21. Larsson B, Johannesson A, Anderssoni H, Atroshi I. The locomotor Capabilities index; validity and reliability of the Swedish version in adults with lower limb amputation. Health Quallife Outcomes 2009;23:7-44.

22. Tomašević $M$, Ružić $V$, Dragović $M$, Gluhak D, Beg N. Samopercepcija osoba $s$ amputacijom donjih ekstremiteta. Physiotherapia Croatica 2016;2:90-4.

\section{PRILOG}

\section{Upitnik za procjenu pokretljivosti osoba nakon amputacije}

$\begin{array}{lllllll}\text { Desni ekstremitet: } & \square \text { PF } & \square T T & \square \mathrm{KD} & \square \mathrm{TF} & \square \mathrm{HD} & \square \text { intaktni } \\ \text { Lijevi ekstremitet: } & \square \mathrm{PF} & \square \mathrm{TT} & \square \mathrm{KD} & \square \mathrm{TF} & \square \mathrm{HD} & \square \text { intaktni }\end{array}$

1. Održavanje ravnoteže sjedeći: sjedi na stolici, prekriženih ruku na prsima u trajanju od 60 sekundi (s)

$0=$ ne sjedi samostalno i uspravno $60 \mathrm{~s}$

$1=$ može sjediti samostalno i uspravno $60 \mathrm{~s}$

2. Doseg sjedeći: nagnuti se naprijed i dohvatiti ravnalo (ispitivač drži ravnalo na udaljenosti od $30 \mathrm{~cm}$ izvan dosega ruku, u ravnini prsne kosti)
$0=$ bez pokušaja
$1=$ ne može dohvatiti ili je potrebna potpora ruke
2 = doseže naprijed i uspješno zahvaća predmet

3. Transfer između dviju stolica: stolice su pod kutom od $90^{\circ}$, smjer odabire pacijent i može koristiti gornje ekstremitete
$0=$ ne izvodi test ili je potrebna pomoć
1 = izvodi samostalno uz nestabilnost
2 = izvodi samostalno, stabilno i sigurno 
4. Ustajanje sa stolice: pacijent drži ruke prekrižene na prsima i ustaje. Ako nije u stanju, dopušteno je korištenje ruku ili pomagala.

$0=$ ne izvodi bez pomoći (fizička pomoć)

1 = izvodi uz pomoć ruku ili pomagala

2 = izvedivo bez pomoći

5. Pokušaj ustajanja iz stolice (korištenje štoperice): ako je ustajanje iz stolice u prethodnom pitanju (br. 4) bilo bez korištenja ruku, zanemari i prijeđi na sljedeći zadatak bez bodovanja

$0=$ ne izvodi bez pomoći (fizička pomoć)

1 = izvodi, potrebno više od 1 pokušaja

2 = izvodi u 1 pokušaju

6. Test ravnoteže u uspravnom stavu (prvih $5 \mathrm{~s}$ ): mjerenje započinje odmah pri ustajanju

$0=$ nestabilnost (pomiče stopala, njiše se)

1 = stabilan koristeći pomagalo ili pomoć druge osobe

2 = stabilan bez pomagala ili pomoći druge osobe

7. Test ravnoteže u uspravnom stavu (30 s): prvi pokušaj izvodi se bez pomoći. Ako je potrebno, pomoć se dopušta nakon prvog pokušaja.
$0=$ nestabilan
1 = stabilan uz pomoć pomagala ili druge osobe
2 = stabilan bez pomagala ili druge sobe

8. Stajanje na jednoj nozi (korištenje štoperice): mjerimo vrijeme stajanja najprije na ostatnom ekstremitetu, a potom na protezi do $30 \mathrm{~s}$. Vrednuje se kvaliteta, a ne vrijeme.

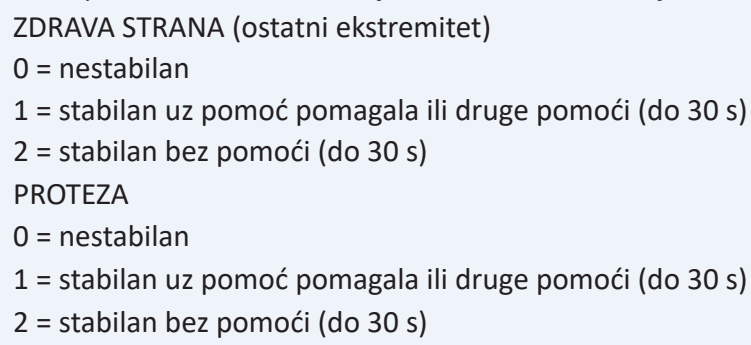

9. Doseg stojeći: nagnuti se naprijed i dohvatiti ravnalo (ispitivač drži ravnalo na udaljenosti od $30 \mathrm{~cm}$ izvan dosega ruku, u ravnini prsne kosti).
$0=$ bez pokušaja
1 = ne može dohvatiti ravnalo, potrebna potpora ruku ili pomagala
2 = doseže naprijed i zahvaća predmet bez pomoći

10. Test guranja (pacijent u uspravnom stavu): noge su postavljene čim bliže jedna drugoj, ispitivač postavlja ruku na prsnu kost i gura prema straga 3 puta (prsti bi se trebali odizati od podloge).
$0=$ počinje padati
$1=$ nestabilan, ljulja se i hvata za pomagala
2 = stabilan

11. Test guranja, oči su zatvorene (pacijent je uspravan u stavu): ako je potrebna pomoć ocjenjujemo kao nestabilno.

$$
\begin{aligned}
& 0=\text { nestabilan } \mathrm{i} \text { hvata pomagalo } \\
& 1=\text { stabilan bez pomagala }
\end{aligned}
$$

12. Podizanje predmeta s poda (podizanje olovke s poda koja je udaljena $30 \mathrm{~cm}$ od prednjeg dijela stopala).
$0=$ ne može podignuti predmet s poda i vratiti se u uspravni položaj
1 = podiže predmet uz pomoć (stola, stolice, pomagala)
2 = podiže predmet bez pomoći

13. Posjedanje: zamolimo pacijenta da prekriži ruke preko prsa i sjedne. Ako se može, dopušteno je korištenje ruku i pomagala.

$0=$ nesigurnost (kriva procjena udaljenosti, pada u stolicu)

1 = koristi ruke ili pomagalo uz naglo spuštanje u stolicu

2 = sigurno se posjeda 
14. Inicirani hod (odmah po naredbi »kreni«).

0 = oklijevanje, višestruki pokušaji starta

1 = bez oklijevanja, odmah starta

15. Dužina i visina koraka. Prohodati naprijed i natrag izmjerenu dužinu od $3,7 \mathrm{~m}$. Potrebno je 4 mjerenja, odnosno 2 (a i b) za svaku nogu. »Značajna devijacija označava ekstremne zamjenske pokrete koji omogućuju odizanje stopala od poda.

a. stopalo u fazi njihanja

Ne napreduje $u$ iskoraku minimalno $30 \mathrm{~cm}=0$

Napreduje u iskoraku u minimalno $30 \mathrm{~cm}=1$

Proteza Ostatna noga

b. odizanje stopala

Stopalo se $u$ potpunosti ne odiže od poda bez devijacije pokreta $=0$

Stopalo se bez devijacije pokreta u potpunosti odiže od poda $=1$

16. Kontinuirani hod.

0 = zaustavljanje ili prekid između koraka (»stop \& go hod «)

$1=$ kontinuirani hod

17. Okret za $180^{\circ}$ pri povratku na stolicu.

$0=$ nemogućnost okreta

1 = potrebno je više od 3 koraka, test izvršava bez pomoći

2 = potrebno je manje od 3 koraka, s ili bez pomoći

18. Promjena brzine hoda. Prohodati udaljenost od $3,7 \mathrm{~m}$, brzo i sigurno, ponoviti 4 puta (brzina može varirati od sporo prema brzo i obrnuto, različitim ritmom).

$0=$ ne može mijenjati brzinu hoda

1 = neravnomjerna promjena brzine hoda

2 = ravnomjerna promjena brzine hoda

19. Hod preko prepreka: staviti kutiju visine $10 \mathrm{~cm}$ na pješačku stazu.

$0=$ ne može prekoračiti

1 = zapinje stopalom, isprekidan korak

2 = savladava prepreku bez zastoja $u$ hodu

20. Stepenice (najmanje 2 stepenice): Savladati hod uz i niz stepenice bez pomoći rukohvata. Sigurnost je na prvom mjestu, ako ispitivač ocijeni da postoji i mali rizik, test ne izvodimo, ocjenjujemo s 0.

UZ STEPENICE

$0=$ nesigurnost, ne izvodi

1 = korak po korak uz rukohvat

2 = korača po stepenicama bez pomoći

NIZ STEPENICE

$0=$ nesigurnost, ne izvodi

1 = korak po korak uz rukohvat

2 = korača po stepenicama bez pomoći

21. Selekcija pomagala: dodati bodove ako koristi 2 ili više pomagala. Ako se provodi bez proteze korištenje odgovarajućeg pomagala obavezno.
$0=$ rub kreveta
$1=$ kolica
$2=$ hodalica
3 = štake (potpazušne ili podlaktne)
$4=$ štap
$5=$ bez pomagala

PF - parcijalna amputacija stopala; TT - potkoljena amputacija; KD - dezartikulacija u koljenu; TF - natkoljena amputacija; HD - dezartikulacija u kuku. 